\title{
Cardiac Troponin $T$ capture and detection in real-time via epitope-imprinted polymer and optical biosensing
}

P. Palladino

M. Minunni

S. Scarano

simona.scarano@unifi.it

Department of Chemistry 'Ugo Schiff', University of Florence, 50019 Sesto Fiorentino (FI)(FI), Italy

${ }^{*}$ Corresponding author

Abstract

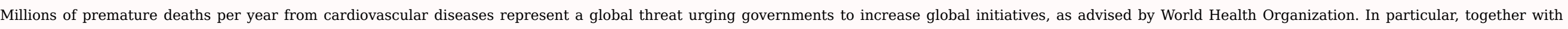

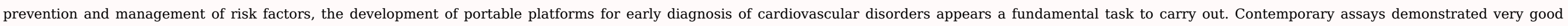

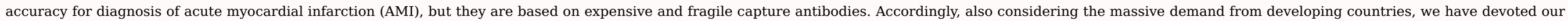

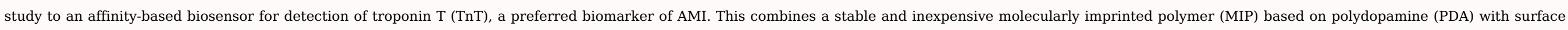

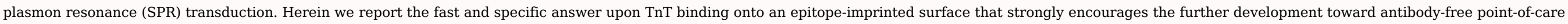
testing for cardiac injury.

Keywords: Acute myocardial infarction; Troponin T; Surface Plasmon Resonance; Polydopamine; Molecularly Imprinted Polymer; Epitope-Imprinted Biosensor

\section{Introduction}

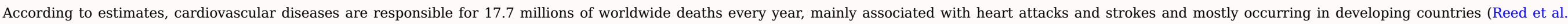

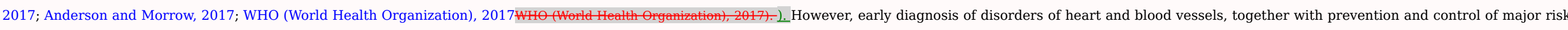

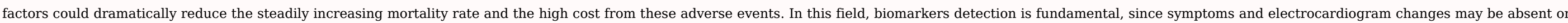

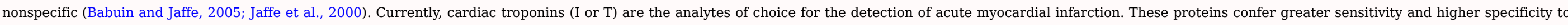

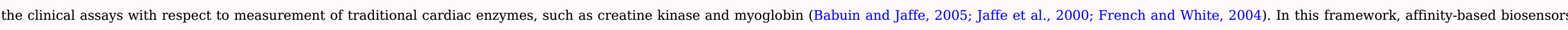

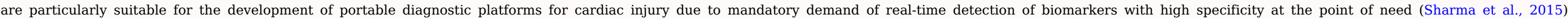

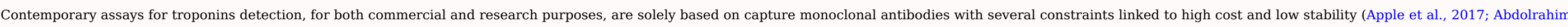

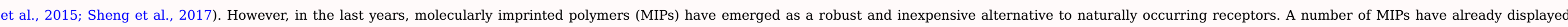

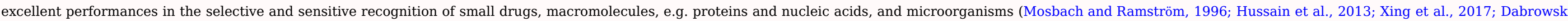

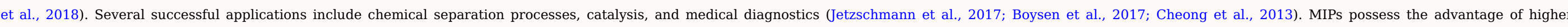

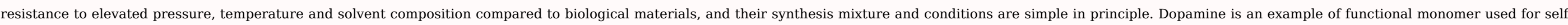

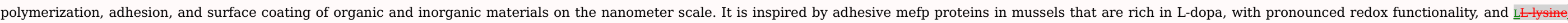

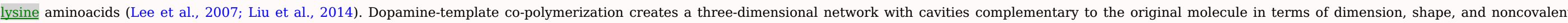

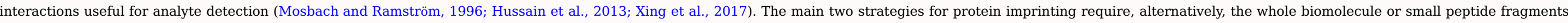

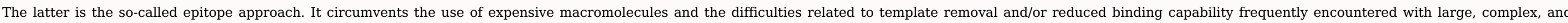

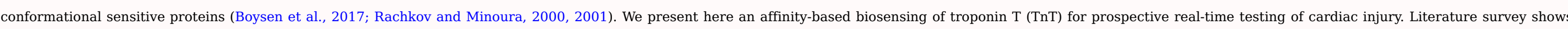




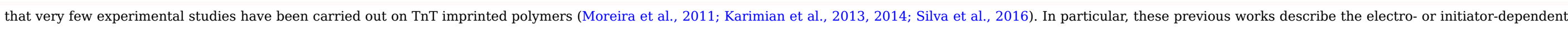

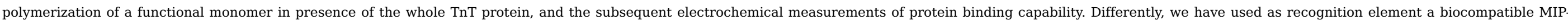

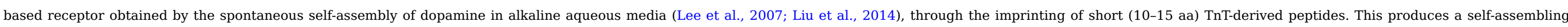

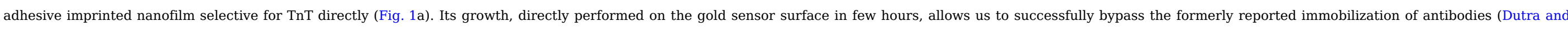

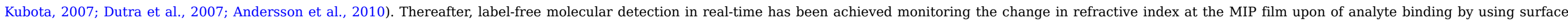

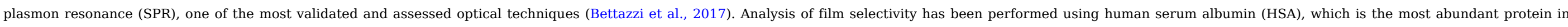

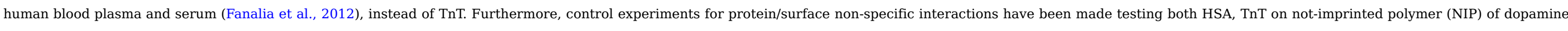

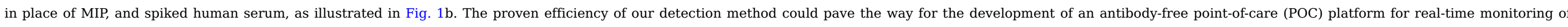

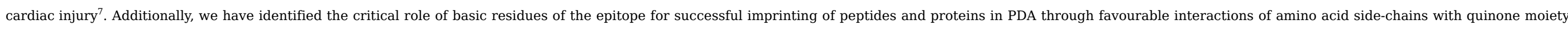

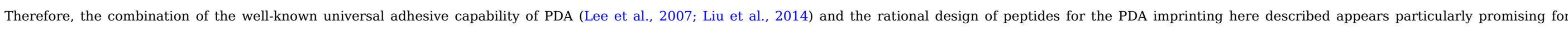
biosensors research and application.

a

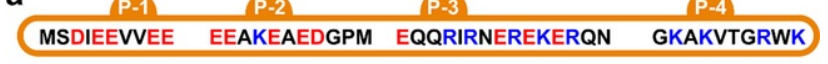

b

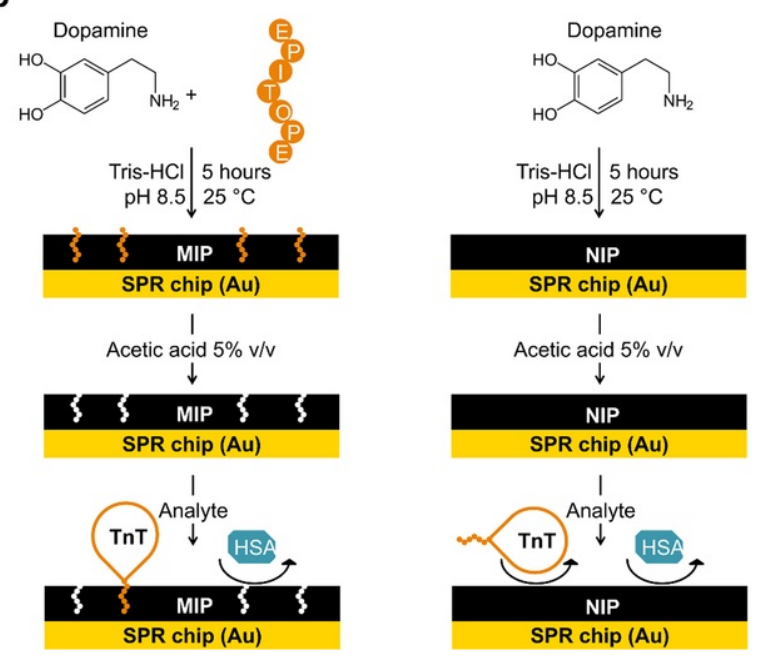

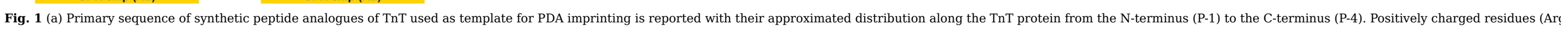

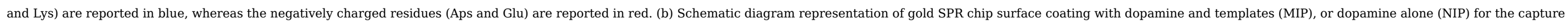
and detection of analytes.

\section{alt-text: Fig. 1}

\section{Materials and methods}

\subsection{Reagents and chemicals}

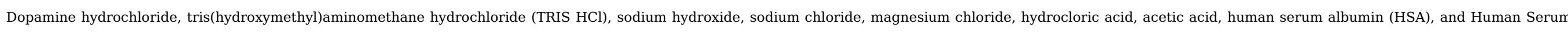

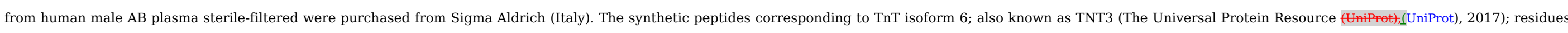

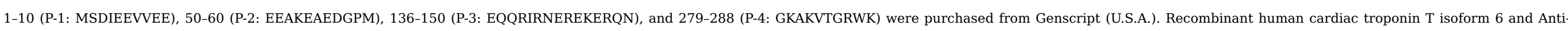




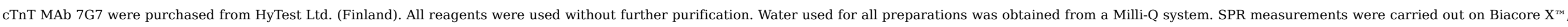
by using bare gold chips (General Electric Healthcare, Sweden).

\subsection{Setup for surface plasmon resonance measurements}

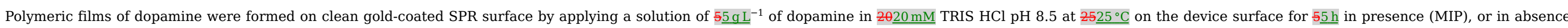

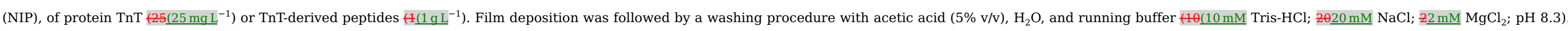

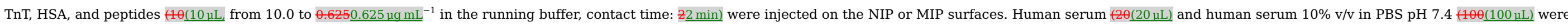

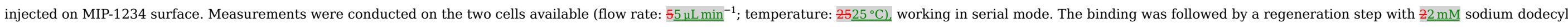
sulphate (SDS) and/or $1010 \mathrm{mM}$ HCl. Sensorgrams were elaborated by BIAevalutation 3.1 software.

\section{Results and discussion}

\subsection{Evaluation of proteins interaction with whole protein-based MIP}

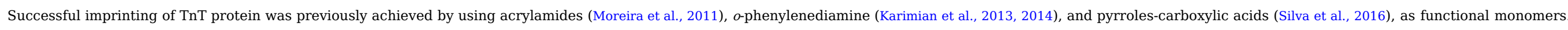

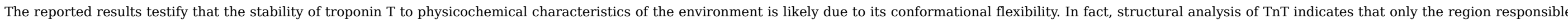

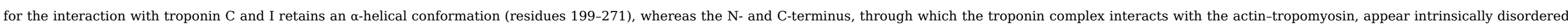

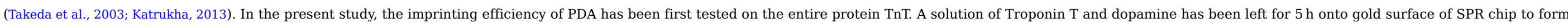

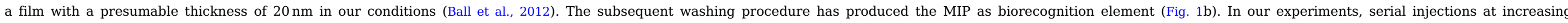

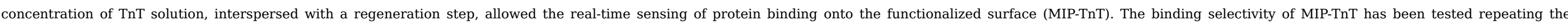

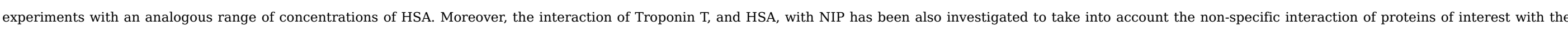

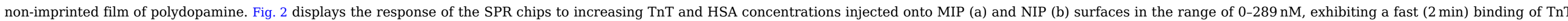

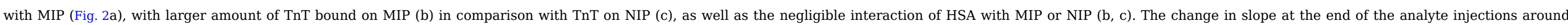

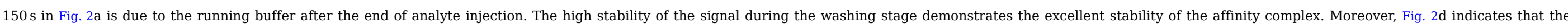

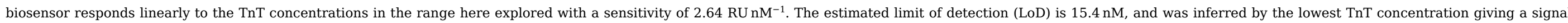

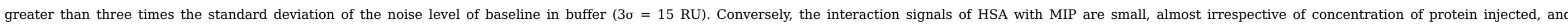

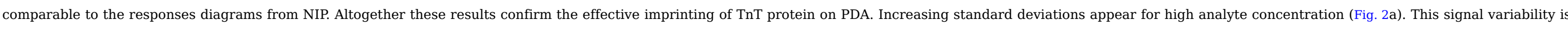

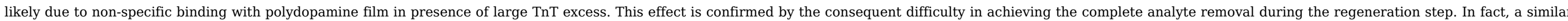

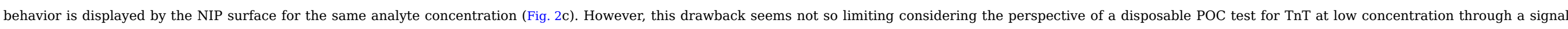
amplification strategy (Lisi et al., 2017; O'Connor et al., 2016). 

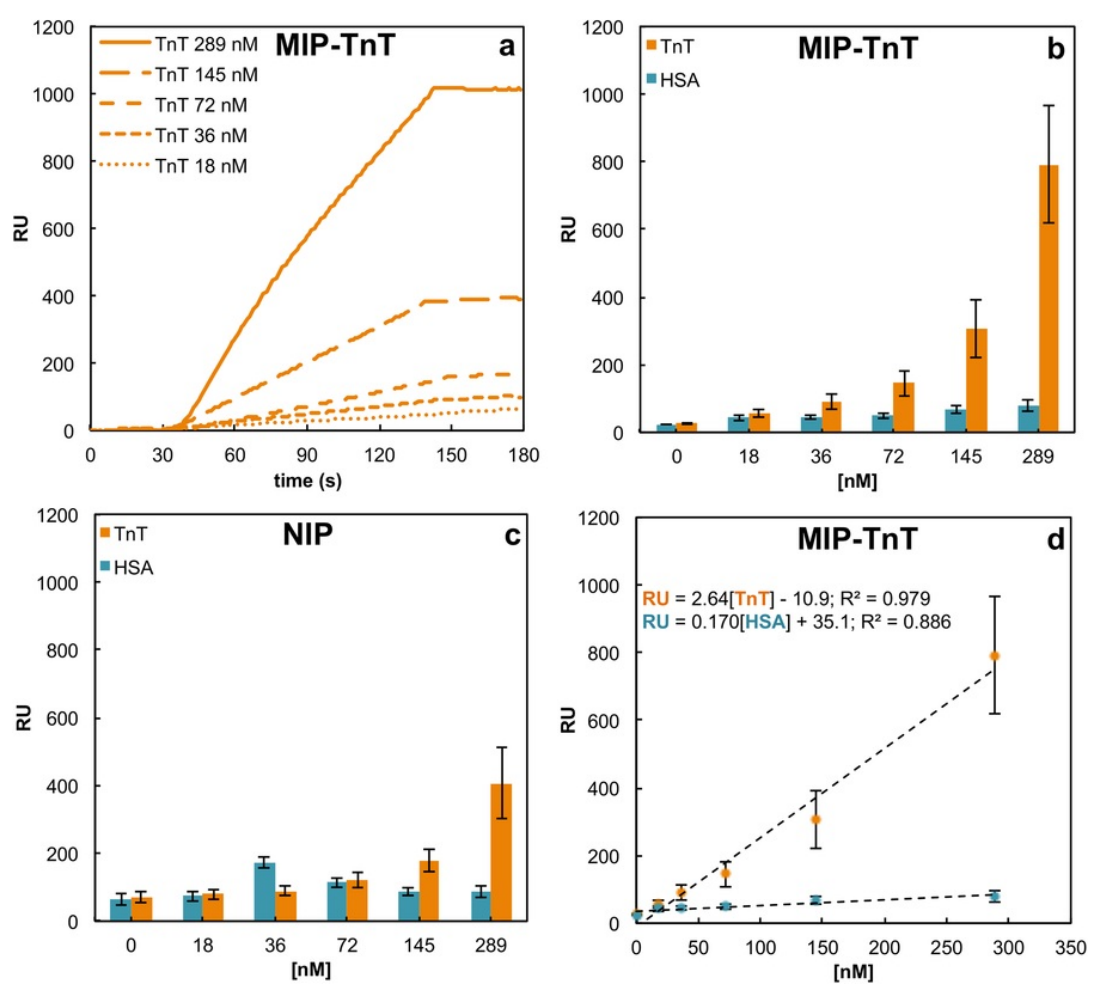

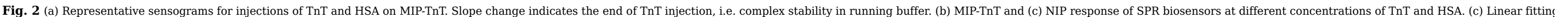
of MIP response to TnT and HSA injections. We have analyzed four replicates for each analyte concentration, intersperse with a regeneration step, and reported the mean value and the standard deviation as error bars.

\section{alt-text: Fig. 2}

\subsection{Rational selection of peptide fragments and analysis of TnT Epitope-imprinting}

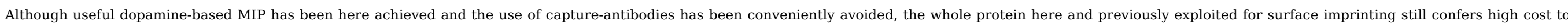

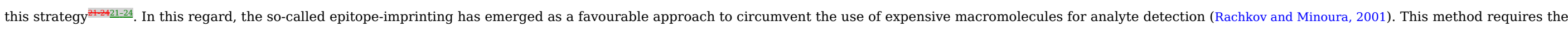

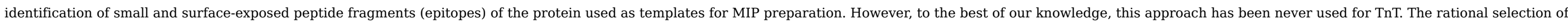

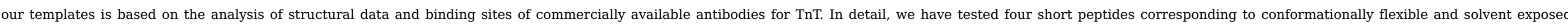

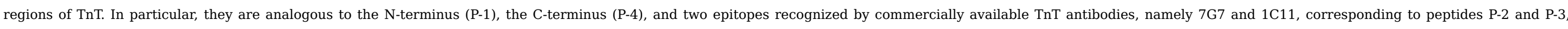

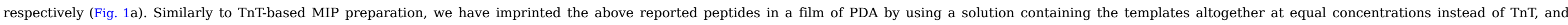

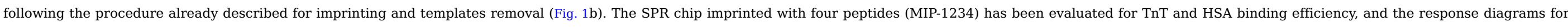

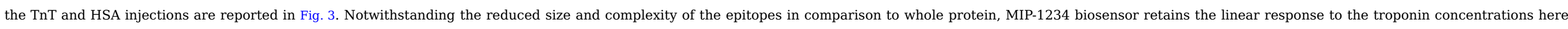

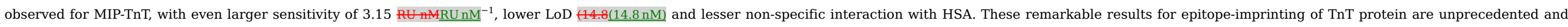
move us closer to achieving the original intent, i.e. the development of affordable real-time antibody-free testing for cardiac injury. 

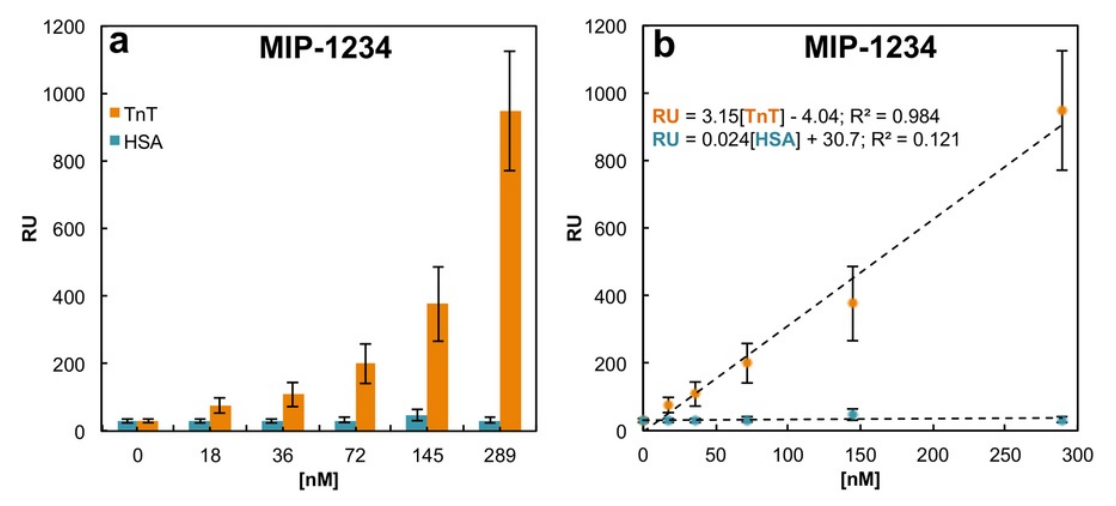

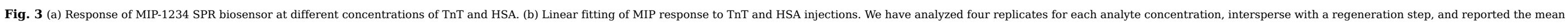
value and the standard deviation as error bars.

\subsection{Investigation of MIP based on single TnT-epitope}

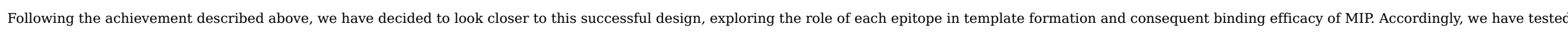

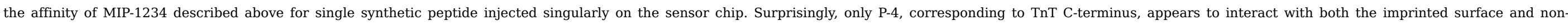

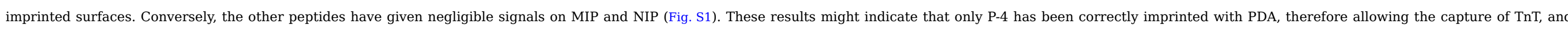

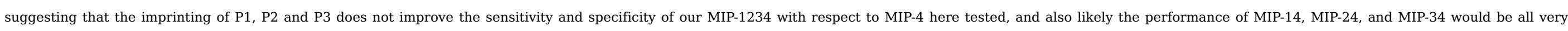

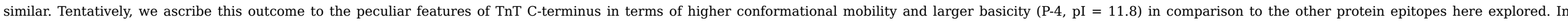

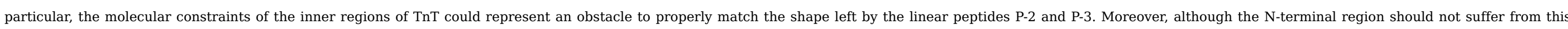

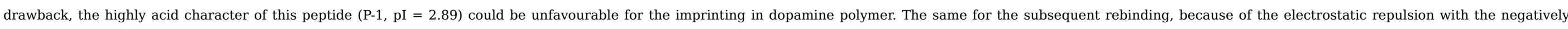

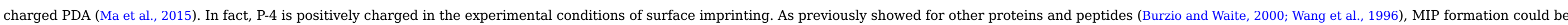

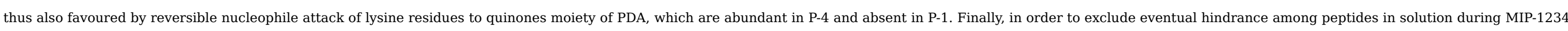

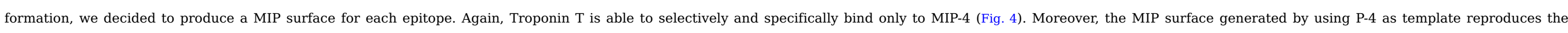

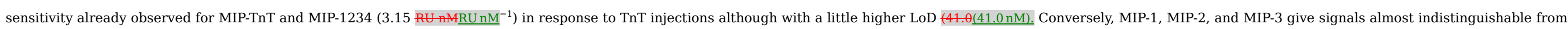
NIP (Fig. S2).
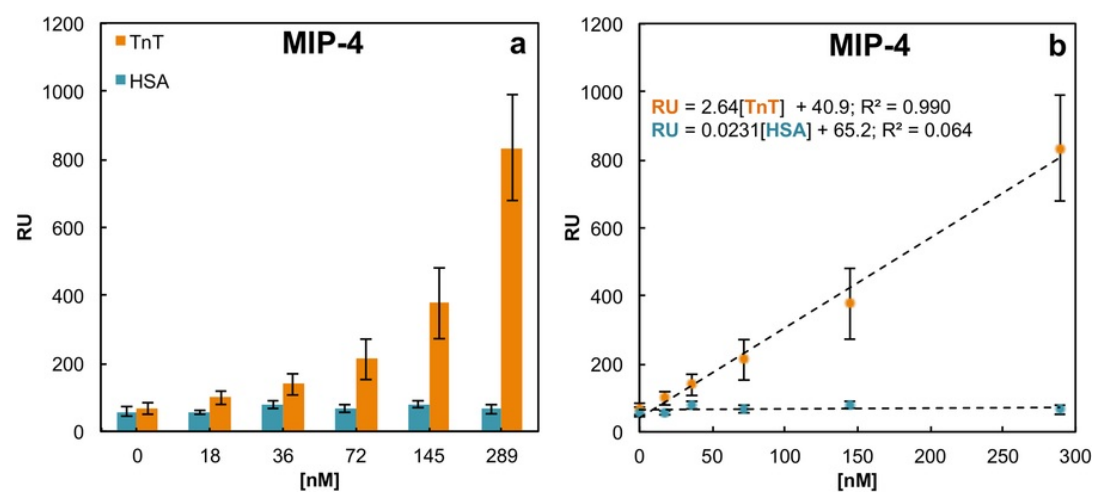

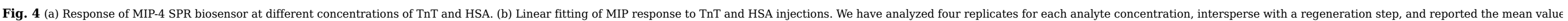




\subsection{TnT detection from spiked human serum}

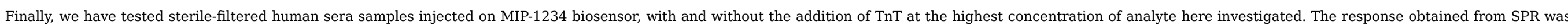

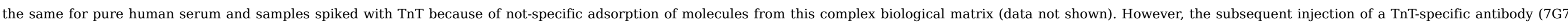

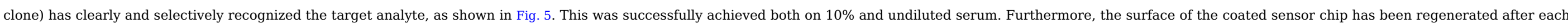

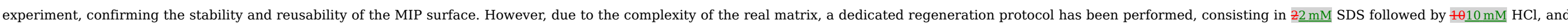

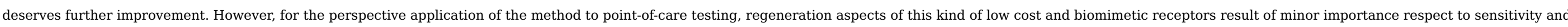
selectivity. Ongoing work is dedicated to the amplification of the detection limit by substituting the 7G7 antibody with a secondary synthetic receptor.

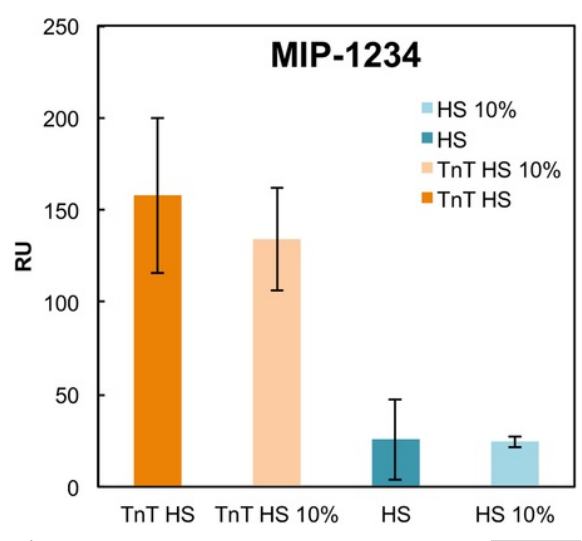

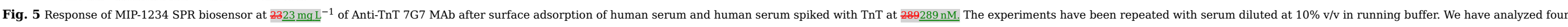
replicates for each analyte concentration, intersperse with a regeneration step, and reported the mean value and the standard deviation as error bars.

alt-text: Fig. 5

\section{Conclusions}

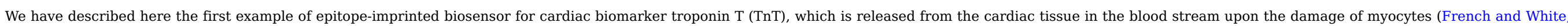

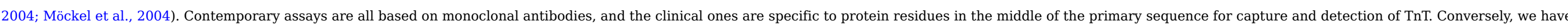

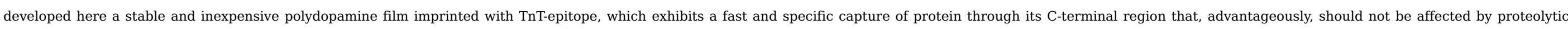

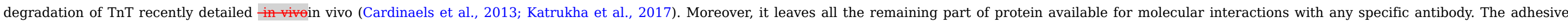

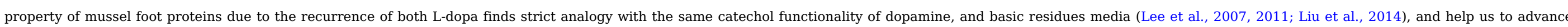

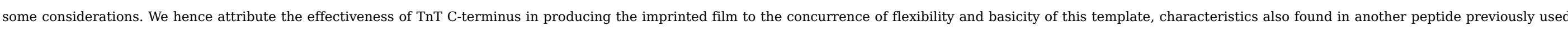

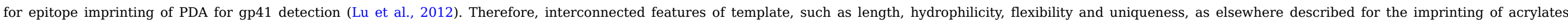

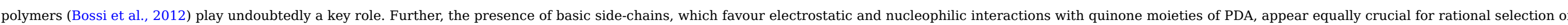

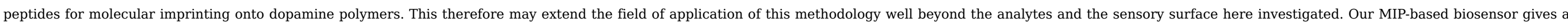

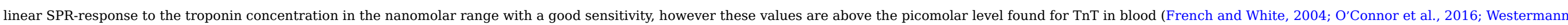

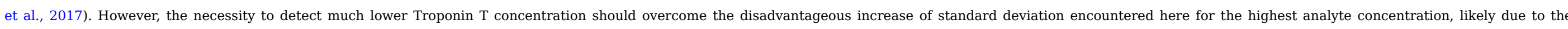

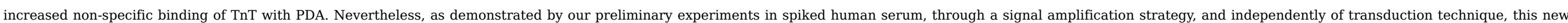




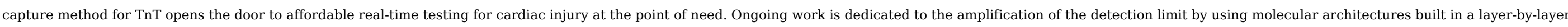
fashion, biomolecules and nanostructures, as also recently reported (Lisi et al., 2017; O'Connor et al., 2016). Uncited referenees(Unipret; Who)

\section{Acknowledgements}

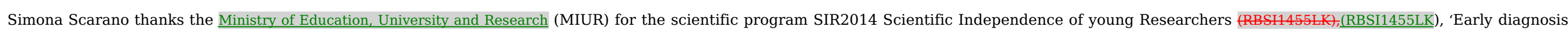
of acute myocardial infarction by nanosensing: coupling emerging bioreceptors for Troponin T to Localized Surface Plasmon Resonance (LSPR) for a high sensitive point-of-care testing'.

\section{Appendix A. Supplementary material}

Supplementary data associated with this article can be found in the online version at doi:10.1016/j.bios.2018.01.068.

\section{References}

Abdolrahim M., Rabiee M., Alhosseini S.N., Tahriri M., Yazdanpanah S. and Tayebi L., Amalyeal Biochem. 2015, 1-10.

Anderson J.L. and Morrow D.A., The Nowgland Joumal of MedieineN. Engl. J. Med. 376, 2017, 2053-2064.

Andersson H., Kågedal B. and Mandenius C.-F., Analytical and Bioandytical ChemistryAnal. Bioanal. Chem. 398, 2010, 1395-1402.

Apple F.S., Sandoval Y., Jaffe A.S. and Ordonez-Llanos J., Elinical Chemitry Clin. Chem. 63, 2017, 73-81.

Babuin L. and Jaffe A.S.,

Ball V., Del Frari D., Toniazzo V. and Ruch D., fournal of I. Colloid Interface Seience Sci. 386, 2012, 366-372.

Bettazzi F., Marrazza G., Minunni M., Palchetti I. and Scarano S., Analytieal Chemistry Anal. Chem. 77, 2017, 1-13.

Bossi A.M., Sharma P.S., Montana L., Zoccatelli G., Laub O. and Levi R., Analytical ChemistryAnal. Chem. 84, 2012, 4036-4041.

Boysen R.I., Schwarz L.J., Nicolau D.V. and Hearn M.T.W., foumal of Separation Seieneel. Sep. Sci. 40, 2017, 314-335.

Burzio L.A. and Waite J.H., Biochemistry 39, 2000, 11147-11153.

Cardinaels E.P., Mingels A.M., van Rooij T., Collinson P.O., Prinzen F.W. and van Dieijen-Visser M.P., Elinieal Chemistry Clin. Chem. 59, 2013, $1083-1090$.

Cheong W.J., Yang S.H. and Ali F., foumal of Sepation Seiencel. Sep. Sci. 36, 2013, 609-628.

Dabrowski M., Lach P., Cieplak M. and Kutner W., Biesensors and BiolectroniesBiosens. Bioelectron. 102, 2018, 17-26.

Dutra R.F. and Kubota L.T., Eliniea ChimieaClin. Chim. Acta 376, 2007, 114-120.

Dutra R.F., Mendes R.K., Lins da Silva V. and Kubota L.T., foumal of Pharmaentieal and Biomedieal Analysisj. Pharm. Biomed. Anal. 43, $2007,1744-1750$.

Fanalia G., di Masi A., Trezza V., Marino M., Fasano M. and Ascenzi P.,

French J.K. and White H.D., Heart 90, 2004, 99-106.

Hussain M., Wackerlig J. and Lieberzeit P.A., Biosensors 3, 2013, 89-107.

Jaffe A.S., Ravkilde J., Roberts R., Naslund U., Apple F.S., Galvani M. and Katus H., Circulation 102, 2000, 1216-1220.

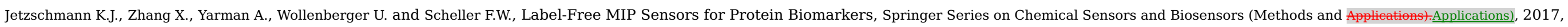

Springer; Heidelberg, 1-31. 


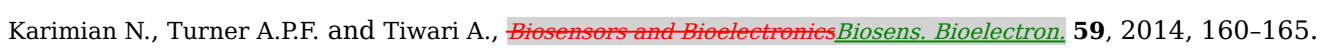

Karimian N., Vagin M., Zavar M.H.A., Chamsaz M., Turner A.P.F. and Tiwari A., Biesensers and BioetectroniesBiosens. Bioelectron. 50, 2013, 492-498.

Katrukha I.A., Biochemistry (Moseon) 78, 2013, 1447-1465

Katrukha I.A., Kogan A.E., Vylegzhanina A.V., Serebryakova M.V., Koshkina E.V., Bereznikova A.V. and Katrukha A.G., Clinical Chemistry Clin. Chem. 63, 2017, 1094-1100.

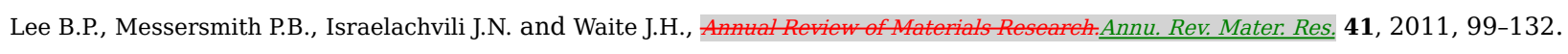

Lee H., Dellatore S.M., Miller W.M. and Messersmith P.B., Science 318, 2007, 426-430.

Lisi S., Scarano S., Fedeli S., Pascale E., Cicchi S., Ravelet C., Peryn C. and Minunni M., Biosensors and Bioectentesiosens. Bioelectron. 93, 2017, 289-292.

Liu Y., Ai K. and Lu L.,

Lu C.H., Zhang Y., Tang S.F., Fang Z.B., Yang H.H., Chen X. and Chen G.N., Biosensors and BioelectroniesBiosens. Bioelectron. 31, $2012,439-444$.

Ma A., Xie Y., Xu J., Zeng H. and Xu H., Chement Commin. 51, 2015, 1469-1471.

Möckel M., Danne O., Schmidt A., Goldman M., Müller C., Dietz R. and Wu A.H.B., Eliniea ChimieaClin. Chim. Acta 342, 2004, 83-86.

Moreira F.T.C., Dutra R.A.F., Noronha J.P.C., Cunha A.L., Goreti and Sales M.G.F.,

Mosbach K. and Ramström O., Nature Biotechnogy Nat. Biotechnol. 14, 1996, 163-170.

O'Connor E.F., Paterson S. and De La Rica R., Analytical and Bioanalytical Chemistry Anal. Bioanal. Chem. 408, 2016, 3389-3393.

Rachkov A. and Minoura N., foumal of Chrotography I. Chromatogr. $A$ 889, 2000, 111-118.

Rachkov A. and Minoura N., Biochimiea et Biophysica Biochim. Biophys. Acta 1544, 2001, 255-266.

Reed G.W., Rossi J.E. and Cannon C.P., Lancet 389, 2017, 197-210.

Sharma S., Zapatero-Rodríguez J., Estrela P. and O’Kennedy R., Biosensors 5, 2015, 577-601.

Sheng Q., Qiao X., Zhou M. and Zheng J., AieroehimieaMicrochim. Acta 184, 2017, 1573-1585.

Silva B.V.M., Rodríguez B.A.G., Sales G.F., Sotomayor M.D.P.T. and Dutra R.F.,

Takeda S., Yamashita A., Maeda K. and Maeda Y., Nature 424, 2003, 35-41.

UniprotUniprot.org/uniprot/P45379.

Wang S.X., Mure M., Medzihradszky K.F., Burlingame A.L., Brown D.E., Dooley D.M., Smith A.J., Kagan H.K. and Klinman J.P., Science 273, 1996, 1078-1084. Westermann D., Neumann J.T., Sörensen N.A. and Blankenberg S., Nature Reviews Cardiology Nat. Rev. Cardiol. 14, 2017, 472-483.

WhoWho.int/cardiovascular diseases/en/

Xing R., Wang S., Bie Z., He H. and Liu Z., Nature ProtocolsNat. Protoc. 12, 2017, 964-987.

\section{Appendix A. Supplementary material}

Multimedia Component 1 
Highlights

- Troponin $\mathrm{T}$ is the most sensitive and selective biomarker of acute myocardial

- Emergency and clinical tests for TnT are still based on immuno-reactions and

- Here the first TnT biosensor based on epitope imprinting on polydopamine is presentedpresented.

- Epitope imprinting with short peptides from TnT allowed low-cost and fast

- Direct assays in standard solutions and sandwich assays on spiked serum are

\section{Queries and Answers}

Query:

Please confirm that given names and surnames have been identified correctly and are presented in the desired order, and please carefully verify the spelling of all authors.

Answer: Yes, all the names are correct.

Query:

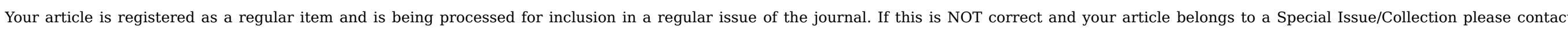
a.elumalai@elsevier.com immediately prior to returning your corrections.

Answer: The article is a regular item for regular issue of the journal. 